\title{
Covid-19 Pandemisinin Hemşirelik Öğrencilerinin Beslenme ve Hijyen Alışkanlıklarına Etkisi
}

\author{
Eda ÜNAL ${ }^{1}$, Aysel ÖZDEMIR ${ }^{2}$, Cevriye YÜKSEL KAÇAN ${ }^{2}$ \\ 1 Bursa Uludağ Üniversitesi Sağlık Bilimleri Enstitüsü, Hemşirelik Anabilim Dalı, Bursa. \\ 2 Bursa Uludağ Üniversitesi Sağlık Bilimleri Fakültesi, Halk Sağlığı Hemşireliği Anabilim Dalı, Bursa.
}

\section{ÖZET}

Bu çalıșmanın amacı, Covid-19 pandemisinin hemșirelik öğrencilerinin beslenme ve hijyen alıșkanlıklarına etkisini belirlemektir. Araștırma kesitsel tipte olup 2019-2020 tarihleri arasında Bursa Uludağ Üniversitesi Sağlık Bilimleri Fakültesi öğrencileriyle internet yoluyla yürütüldü. Araştırmanın evrenini 155 öğrenci oluşturmakta olup örnekleme yapılmamış evrenin tümüne ulaşılmaya çalışılmış, araştırmaya katılmayı kabul eden 126 öğrenci örneklemi oluşturmuştur (\%81). Öğrencilerin yaş ortalamas1 21,52 $\pm 1,47$ y1ldır. Öğrencilerin \% 68,3'ünün pandemi süresince kilo aldığı belirlendi. Covid-19 pandemisinde ögrencilerin günlük C vitamini, kurubaklagil, prebiyotik, probiyotik, zerdaçal, zencefil gibi baharat ve bitki tüketimi artarken, asitli/gazlı içecek, abur cubur gıda tüketimi ve ayaküstü beslenme alışkanlığının azaldığı saptandı $(p<0,05)$. Covid-19 pandemisinde öğrencilerin (günlük sık kullanılan eşyaları, yüzeyleri çamaşır suyuyla temizleme; evi iki saatte bir havalandırma gibi) ev hijyen uygulamaları ile (bir metre sosyal mesafe koyma, tokalaşmama gibi) kişisel hijyen uygulamalarının arttığı tespit edildi(p<0,05). Karantina gibi olumsuz görülen bir sürecin olumlu beslenme davranışı kazanmada etkili olduğu, diğer taraftan kilo artı̧̧ına sebep olduğu bulundu. Hemşirelik öğrencilerinin çoğunluğunun kişisel hijyen uygulamaları pandemi öncesinde de yüksek olduğu pandemiye özgü kişisel hijyen uygulamalarına yüksek oranda uyum sağlandığı tespit edildi.

Anahtar Kelimeler: Covid-19. Beslenme. Hijyen. Öğrenci. Etki. Karantina. Hemşirelik.

Impact of the Covid-19 Pandemic on Feeding and Hygiene Habits of Nursing Students

\begin{abstract}
The purpose of this study is to determine the impact of the Covid-19 pandemic on feeding and hygiene habits of nursing students. The research is a cross-sectional type and was conducted with the students of Bursa Uludağ University Faculty of Health Sciences online between 2019-2020. The universe of the study consists of 155 students, and it was attempted to reach the entire population without sampling, and 126 students (81\%) agreed to participate in the study.Mean age of the students was $21.52 \pm 1.47$ years. It was determined that $68.3 \%$ of the students had gained weight during the pandemic process. In the covid-19 pandemic the students increased daily consumption of vitamin C, legume, prebiotics, probiotics and spices and vegetables such as turmeric, ginger; while they reduced consumption of acid/fizzy drinks, junk food and fast food $(\mathrm{p}<0.05)$. It was found that the students increased home hygiene applications (such as cleaning frequently used daily wares and surfaces with bleacher, airing the house every two hours and personal hygiene applications (such as keeping a social distance of one meter, avoiding hand-shake in the covid-19 pandemic $(\mathrm{p}<0.05)$. It was found that quarantine which is usually considered to be a negative process, was effective on earning positive feeding behaviors on one hand and caused weight gain on the other. It was determined that most nursing students had had higher personal hygiene applications even before the pandemic and they largely adapted to pandemic-related personal hygiene applications.
\end{abstract}

Key Words: Covid-19. Feeding. Hygiene. Student. İmpact. Quarantine. Nursing.

Geliş Tarihi: 08.Eylül.2020

Kabul Tarihi: 22.Ekim.2020

Dok. Öğr. Eda ÜNAL

Bursa Uludağ Üniversitesi Sağlık Bilimleri Enstitüsü, Hemşirelik Anabilim Dalı,

Bursa

Tel: 05303490135

E-posta: edaunal@uludag.edu.tr

Yazarların ORCID ID Bilgisi:

Eda ÜNAL: 0000-0002-9247-9594

Aysel ÖZDEMIR 0000-0002-0815-9505

Cevriye YÜKSEL KAÇAN: 0000-0002-1316-8617
Covid-19 tüm dünyayı etkisi altına alan, acil müdahale edilmesi gereken bir sağlık krizidir ${ }^{1}$. Çin'in Wuhan kentinde Aralık ayında ilk defa görülmeye başlayan koronavirüs (Covid-19) kısa sürede Antarktika dışında tüm kıtalara yayılarak, birçok kişinin enfekte olmasına ve ölümüne neden oldu ${ }^{2,3}$. Ülkemize girişi tam bilinmemekle birlikte ilk resmi koronavirüs vakaları Mart ayında bildirildi ${ }^{4}$.

Nisan 2020'de dünya çapında 3 milyondan fazla vaka ve 200000'den fazla ölüm bildirildi. Hizlı sosyal uzaklaşmanın, toplu ulaşımın, sokağa çıkmanın, enfekte bireylerin izole edildiği, temaslıların karantinaya 
alındığı Kore Cumhuriyeti, Tayvan ve Vietnam dahil bir çok Asya ülkesinde önemli yayılım olmazken, Avrupa ülkelerinde ve ABD'de önemli yayılım oldu $^{5}$.Mayıs ayında Covid-19'un bir milyon nüfusta insidansı Türkiye'de 1,514; iken Avrupa ülkelerinde 1,811; ABD'de 3,664'tür. Covid-19 mortalite oranı Türkiye'de \%2,71, Avrupa ülkelerinde 6,57, ABD'de 5,77'dir. İyileşme oranları ise Türkiye'de 53,40, Avrupa ülkelerinde 45,94, ABD'de 15,50'dir'.

Covid-19 dünyada çocuk ve ergenleri daha az etkilerken 20 ile 70 yaş arasındaki insanları enfekte ve hasta etti ${ }^{5}$. Komplikasyon oranları büyük ölçüde yaşa ve komorbiditelere bağlı olarak değiști.

Covid-19'un insandan insana damlacik yoluyla bulaşması ve bu enfekte damlacıkların yüzeylerde asılı kalması, enfekte olmayan bireylerin bu yüzeylere temas ettikten sonra ellerini ağız, burun veya göz mukozasına taşıması yayılımı hızlandırdı. Ülkeler Covid-19 enfeksiyonunun yayılımı azaltabilecek henüz bir aşının ve onaylanan bir ilacın bulunmaması nedeniyle enfeksiyon zincirini kırabilmek için karantina, izolasyon, hijyen, mesafe gibi geleneksel halk sağlığı önlemleri aldı ${ }^{7}$.

Ülkemizde de vakaların bildirildiği günden bu yana seyahat kısıtlamaları, toplu etkinliklerin iptali, işyerleri ve okulların kapatılması, karantina, halkın eğitimi, sosyal mesafeli kontrollü yaşam gibi önlemler uygulandi.

Covid- 19'unun yayılmasının önlenmesi için halkın uyması gereken ana temaları içeren (hijyen, sosyal mesafe ve karantina) rehberler yayınlandi. Bu rehberlerde yer alan dikkat etmemiz gereken hijyen kurallarl; öksürme/hapşırma, ağız/buruna dokunulduktan, kontamine yüzeylere temas edildikten sonra ellerin y1kanması, el dezenfektanı kullanılması, ellerin gün içinde sık sık en az 20 saniye boyunca mutlaka sabunlu su ile yıkanması veya dezenfektan ile temizlenmesi, mümkün olduğunca eller ile yüze, göze ve ağıza dokunulmaması, sosyal mesafedir. Ayrıca sık kullanılan yüzeyleri, tuvalet gibi ortak alanları günlük seyreltilmiş $\% 0,5$ sodyum hipoklorit ile dezenfekte edilmesi, kontamine olmuş giyecekleri ve çarşafları $60-90^{\circ} \mathrm{C}$ de çamaşır deterjanı ile yıkanması, maske hijyeni, dışarıdan eve getirilen paketli/paketsiz gıdaların da uygun temizlenmesi yer almaktadır. Covid-19 pandemisinin, toplumlarda hijyen ve temizlik konusundaki alı̧sanlıkları tümüyle etkileyeceği söylenmektedir ${ }^{8-10}$.

Virüsün yayılımını azaltmak için uygulanan karantina, toplumun yeme alışkanlıklarını etkileyerek, raf ömrï uzun işlenmiş gıdaların depolanmasına, evlerde depolanan bu gidalar evleri obejenik hale dönüștürdü. İzole olma, eve kapanma, bilinmezliğin oluşturduğu stres bireylerin yemek yemelerini tetikleyerek obezite riskini arttıracağ $\breve{1}$ endişesi bildirildi ${ }^{11,12}$. Covid-19 viral enfeksiyonu bağışıklığı düşük insanları daha kolay etkilemektedir ${ }^{12}$. Dünya Sağlık Örgütü ve Sağlık Bakanlığı yayınladığı rehberlerle korona virüsten kaynaklanan duyarlılığı ve uzun süreli komplikasyonları azaltabilmek için yeterli ve dengeli beslenmeye özen gösterilmesi ve sağlıklı gıdaların tercih edilmesi önerilerinde bulundu ${ }^{13}$. Covid-19'a karşı beslenme önerileri immün sistemi güçlü tutabilecek günlük yeşil yapraklı sebze, lif bakımından zengin olan baklagil ve tahıl, C vitamini, meyve ve sebze tüketilmesi; doymamış yağların tercih edilmesi; haftada iki kez et, balık, kümes hayvan proteini tüketilmesi; en az 8-10 bardak su tüketilmesi; gazlı içecekler ve şekerlerden uzak durulması; düzenli egzersiz ve yeterli uyku, meditasyondur $^{12,14}$. Bunlara ek olarak sigara ve alkolden kaçınmak da tavsiye edilmektedir ${ }^{14}$.

Covid-19 pandemisinden korunmak için alınan karantina ve kontrollü sosyal hayat önlemleriyle toplumda yeni bir hayat düzeni șekillendi. Bu hayat düzeninden en çok toplumun hijyen ve beslenme uygulamaları etkilendi. Toplumun sağlığının şekillenmesinde önemli misyonları olan hemşirelerin aldıkları beslenme ve hijyen eğitimleri, edindikleri bilgi, beceri ve uygulamalarıyla pandemi sürecine daha kolay adapte olması beklenmektedir. Bu veriler doğrultusunda bu çalışmanın amacı, Covid-19 pandemisinin hemşirelik öğrencilerinin beslenme ve hijyen alışanlıklarına etkisini incelemektir.

\section{Gereç ve Yöntem}

\section{Araştırmanın Tasarımı}

Kesitsel tipteki bu çalışma, Bursa Uludağ Üniversitesi Sağlık Bilimleri Fakültesi öğrencileri ile ŞubatHaziran 2020 tarihleri arasında internet ortamında gerçekleştirildi.

\section{Örneklem}

Araştırma evrenini 2019-2020 eğitim-öğretim y1lında Bursa Uludağ Üniversitesi Sağlık Bilimleri Fakültesine kayıtlı 3. sınıf Halk Sağlığı Hemşireliği dersi alan tüm öğrenciler oluşturdu $(\mathrm{n}=155)$. Araştırmacılar maksimum çalışma boyutuna ulaşmaya çalışırken örneklem büyüklüğü hesaplanmadı. Bu araştırmaya katılım gönüllüydü, derse devam etmeyen veya anket formlarındaki tüm soruları yanıtlamayan öğrenciler (29 öğrenci, \% 19) araştırmaya dahil edilmedi ve araştırma 126 öğrenci ile yapıldı (\% 81).

\section{Veri Toplama Aracı}

Veriler, araştırmacılar tarafindan literatür taranarak 3 uzman görüşü alınarak oluşturulan; sosyo-demografik veri toplama formu (10 soru), Covid-19 pandemisi süresince beslenme alışkanlıkları anketi (19 soru), Covid-19 pandemisinin beslenme düzeninde yarattı̆̆ 1 değişiklikler anketi (8 soru) ve Covid-19 pandemisi süresince hijyen uygulamaları anketi (20 soru) ile toplandi.

\section{Istatistiksel Analiz}

Verinin istatistiksel analizi IBM SPSS 23.0 (IBM Corp. Released 2015. IBM SPSS Statistics for Win- 


\section{Covid-19 Pandemisinin Öğrencilere Etkisi}

dows, Version 23.0. Armonk, NY: IBM Corp.) istatistik paket programında yapıldı. Verilerin tanımlayıcı istatistikleri ortalama, standart sapma, frekans ve yüzde olarak belirtildi. Bağımlı yapıdaki kategorik verilerin karşılaştırılmasında McNemar testi kullanılarak değerlendirildi. İstatistiksel anlamlılık düzeyi $\mathrm{p}<0,05$ olarak belirlendi.

\section{Araştırmanın Etik Yönü}

Çalışmanın yapılabilmesi için Bursa Uludağ Üniversitesi Sağlık Bilimleri Araştırma ve Yayın Etiği Kurulu’ndan 01.07.2020 tarihli ve 2020-05/02 say1lı etik kurul izni, Sağlık Bilimleri Fakültesi Dekanlığı'ndan da 45226392-605/E.334 sayılı çalışma izni alındı.

\section{Bulgular}

Öğrencilerin yaş ortalaması 21,52 $\pm 1,47$ y1l， \% 84,1'i kadın ve \%81,7'sinin ekonomik durumu orta düzeydedir. Öğrencilerin \%73,8'i Marmara Bölgesinde, \% 46,0's1 ilçe merkezinde \%59,5'1 apartmanda yaşamaktadır. Öğrencilerin \%59,5'inin kendine ait odası ve \% 66,7 'sinin evinin ortak alanları sosyal mesafeyi koruyacak düzeydedir. Çalışmadaki öğrencilerin \% 45,2'si kronik hastalığı sahip birey ile yaşamakta ve \% 7,9’u sürekli ilaç kullanmaktadır. Çalışmanın sosyodemografik verileri Tablo I’de verildi.

Tablo I. Öğrencilerin Sosyo-Demografik Özelliklerinin Dağılımı

\begin{tabular}{|lrr|}
\hline Özellikler & $\mathbf{n}$ & $\%$ \\
\hline Yaş & & \\
Cinsiyet & & \\
Kadın & 106 & 84,1 \\
Erkek & 20 & 15,9 \\
Ekonomik Durum Algısı & & \\
Orta & 103 & 81,7 \\
lyyi & 23 & 18,3 \\
Yaşadığınız bölge & & \\
Marmara Bölgesi & 93 & 73,8 \\
Diğer Bölgeler & 33 & 26,2 \\
Yaşanılan konutun yapısı & & \\
Müstakil & 51 & 40,5 \\
Apartman & 75 & 59,5 \\
Ailece ikamet edilen yer & & \\
III merkezi & 52 & 41,3 \\
İlçe merkezi & 58 & 46,0 \\
Kasaba & 3 & 2,4 \\
Köy & 13 & 10,3 \\
Evde kendine ait oda varlığı & & \\
Evet & 75 & 59,5 \\
Hayır & 51 & 40,5 \\
Evde ortak yaşam alanların sosyal mesafeye uygunluğu & 84 & 66,7 \\
Evet & 42 & 33,3 \\
Hayır & & \\
Evde kronik hasta varlığı & 57 & 45,2 \\
Evet & 69 & 54,8 \\
Hayır & 10 & 7,9 \\
Sürekli kullanılan ilaç varlığı & 116 & 92,1 \\
\hline Evet & 126 & 100,0 \\
Hayır & & \\
\hline Toplam & & \\
\hline Tan & & \\
\hline
\end{tabular}

Tanımlayıc istatistikler ortalama, standart sapma, frekans ve yüzde olarak belirtildi.
Covid-19 pandemisinde öğrencilerin günlük C vitamini $(p<0,001)$, kurubaklagil $(p<0,001)$, prebiyotik $(p=0,004)$, probiyotik $(p=0,031)$, zerdaçal, zencefil gibi baharat ve bitki tüketimi $(p=0,015)$ artarken, asitli/gazlı içecek $(p=0,007)$, abur cubur gida tüketimi $(p=0,045)$ azald1. Öğrencilerin ayaküstü beslenme alışkanlığında azalma saptandı $(\mathrm{p}<0,05)$. Pandemi öncesinde öğrenciler alışveriş merkezlerini daha çok tercih ederken, pandemi sonrasında online alışveriş sitelerini daha çok tercih etti $(p<0,05)$. Çalışmanın Covid-19 pandemisi öncesi ve sonrasında öğrencilerin beslenme alışkanlıklarının dağılımı ve analizi Tablo II'de verildi.

Tablo II. Covid-19 Pandemisi Öncesi ve Sonrasında Öğrencilerin Beslenme Alışkanlıklarının Dağılımı

\begin{tabular}{|c|c|c|c|}
\hline Beslenme Alışkanlıkları & $\begin{array}{c}\text { Pandemi } \\
\text { Öncesi } \\
\text { n(\%) }\end{array}$ & $\begin{array}{c}\text { Pandemi } \\
\text { Sonrası } \\
\mathrm{n}(\%) \\
\end{array}$ & $p$ \\
\hline \multicolumn{4}{|l|}{3 ana öğünü atlamama } \\
\hline Evet & $50(39,7)$ & $51(40,5)$ & 1,000 \\
\hline Hayır & $76(60,3)$ & $75(59,5)$ & \\
\hline \multicolumn{4}{|l|}{3 ara öğünü atlamama } \\
\hline Evet & $16(12,7)$ & $22(17,5)$ & 0,180 \\
\hline Hayır & $110(87,3)$ & $104(82,5)$ & \\
\hline \multicolumn{4}{|l|}{ Ayaküstü beslenme } \\
\hline Evet & $63(50,0)$ & $31(24,6)$ & $<0,001$ \\
\hline Hayır & $63(50,0)$ & $95(75,4)$ & \\
\hline \multicolumn{4}{|l|}{ Mevsiminde taze sebze/meyve tüketme } \\
\hline Evet & $109(86,5)$ & $116(92,1)$ & 0,118 \\
\hline Hayır & $17(13,5)$ & $10(7,9)$ & \\
\hline \multicolumn{4}{|l|}{ Haftada 2 kez balık tüketme } \\
\hline Evet & $7(5,6)$ & $14(11,1)$ & 0,092 \\
\hline Hayır & $119(94,4)$ & $112(88,9)$ & \\
\hline \multicolumn{4}{|l|}{ Günlük tüketilen besinler } \\
\hline \multicolumn{4}{|l|}{$\begin{array}{l}\text { Bağışıklık için zerdaçal, zencefil gibi } \\
\text { baharat ve bitki tüketme }\end{array}$} \\
\hline $\begin{array}{l}\text { Evet } \\
\text { Hayır }\end{array}$ & \multicolumn{2}{|c|}{ Hayır } & \\
\hline \multicolumn{4}{|l|}{ C vitamini tüketme } \\
\hline Evet & $56(44,4)$ & $88(69,8)$ & $<0,001$ \\
\hline Hayır & $70(55,6)$ & $38(30,2)$ & \\
\hline \multicolumn{4}{|l|}{ Kuru baklagilleri tüketme } \\
\hline Evet & $43(34,1)$ & $60(47,6)$ & $<0,001$ \\
\hline Hayır & $83(65,9)$ & $66(52,4)$ & \\
\hline \multicolumn{4}{|l|}{ Günlük abur cubur (cips, bisküvi, } \\
\hline $\begin{array}{l}\text { Evet } \\
\text { Hayır }\end{array}$ & $61(48,4)$ & $75(59,5)$ & \\
\hline \multicolumn{4}{|l|}{ Günlük tatlı tüketme } \\
\hline Evet & $72(57,1)$ & $83(65,9)$ & 0,063 \\
\hline Hayır & $54(42,9)$ & $43(34,1)$ & \\
\hline \multicolumn{4}{|l|}{ Karbonhidrat/hamur işi ağırlıklı gıda } \\
\hline \multicolumn{4}{|l|}{ Hayır } \\
\hline \multicolumn{4}{|l|}{ Günlük Prebiyotik* tüketme } \\
\hline Evet & $57(45,2)$ & $71(56,3)$ & 0,004 \\
\hline Hayır & $69(54,8)$ & $55(43,7)$ & \\
\hline \multicolumn{4}{|l|}{ Günlük Probiyotik ** tüketme } \\
\hline Evet & $67(53,2)$ & $77(61,1)$ & 0,031 \\
\hline Hayır & $59(46,8)$ & $49(38,9)$ & \\
\hline
\end{tabular}


Tablo II. (Devamı)

\begin{tabular}{|c|c|c|c|}
\hline $\begin{array}{l}\text { Günlük 2/2,5lt su tüketme } \\
\text { Evet } \\
\text { Hayır }\end{array}$ & $\begin{array}{l}82(65,1) \\
44(34,9) \\
\end{array}$ & $\begin{array}{l}93(73,8) \\
33(26,2) \\
\end{array}$ & 0,054 \\
\hline \multicolumn{4}{|l|}{ Günlük asitli/gazlı içecek tüketme } \\
\hline Evet & $43(34,1)$ & $30(23,8)$ & 0,007 \\
\hline Hayır & $83(65,9)$ & $96(76,2)$ & \\
\hline \multicolumn{4}{|l|}{ Gıda alısverişi için en çok marketleri tercih } \\
\hline etme & $102(81,0)$ & $96(76,2)$ & 0,327 \\
\hline Evet & $24(19,0)$ & $30(23,8)$ & \\
\hline \multicolumn{4}{|l|}{$\begin{array}{l}\text { Hayır } \\
\text { Gıda alısverisi icin en cok pazar yerlerini }\end{array}$} \\
\hline tercih etme & $70(55,6)$ & $41(3$ & $<0,001$ \\
\hline Evet & $56(44,4)$ & $85(67,5)$ & \\
\hline $\begin{array}{l}\text { Gıda alışverişi için en çok online siteleri } \\
\text { tercih etme }\end{array}$ & 8 & $18(14,3)$ & 0,022 \\
\hline Evet & $117(92,9)$ & $108(85,7)$ & \\
\hline
\end{tabular}

Öğrencilerin \%86,5'inin evinde yemek hazırlamapişirme işinden anneleri sorumludur. Pandemi döneminde öğrencilerin \% 66,7'sinin evde yemek hazırlama-pişirme, $\% 67,5$ 'inin yemek hazırlama ve pişirmeye ayrılan süre, \% 52,4'ünün yemek çeşidi artarken, \%58,7'sinin eve yemek siparişi azaldı. Araştırmadaki öğrencilerin \% 68,3'ünün kilo ald1ğ1, \%72,2'sinin evde ekmek yaptığı, \%70,6's1 evde yemek yerken sosyal mesafeyi koruyamadı görüldü. Araştırmanın Covid-19 pandemisinin öğrencilerin beslenme düzeninde yarattığı değişikliklerin dağılımı Tablo III'de sunuldu.

Tablo III. Covid-19 Pandemisinin Öğrencilerin Beslenme Düzeninde Yarattığı Değişikliklerin Dağılımı

\begin{tabular}{|c|c|c|}
\hline $\begin{array}{l}\text { Covid-19 Pandemi Döneminde Yemek } \\
\text { Alışkanlıklarındaki Değişiklik }\end{array}$ & $\underline{\mathrm{n}}$ & $\%$ \\
\hline \multicolumn{3}{|l|}{ Evde yemek hazırlama-pişirme işini yapan kişi } \\
\hline Annem & 109 & 86,5 \\
\hline Babam & 1 & 0,8 \\
\hline Kendim & 12 & 9,5 \\
\hline Kardeşim & 2 & 1,6 \\
\hline Diğer & 2 & 1,6 \\
\hline \multicolumn{3}{|l|}{ Evde yemek hazırlama-pişirme } \\
\hline Arttı & 84 & 66,7 \\
\hline Azaldı & 2 & 1,6 \\
\hline Değişmedi & 40 & 31,7 \\
\hline \multicolumn{3}{|l|}{ Yemek hazırlama-pişirmeye ayrılan süre } \\
\hline Arttı & 85 & 67,5 \\
\hline Azaldı & 3 & 2,3 \\
\hline Değişmedi & 38 & 30,2 \\
\hline \multicolumn{3}{|l|}{ Yemek çeşitlerinin sayısı } \\
\hline Arttı & 66 & 52,4 \\
\hline Azaldı & 8 & 6,3 \\
\hline Değişmedi & 52 & 41,3 \\
\hline \multicolumn{3}{|l|}{ Eve yemek sipariși } \\
\hline Arttı & 10 & 7,9 \\
\hline Azaldı & 74 & 58,8 \\
\hline Değişmedi & 42 & 33,3 \\
\hline \multicolumn{3}{|l|}{ Evde ekmek yapımı } \\
\hline Evet & 91 & 72,2 \\
\hline Hayır & 35 & 27,8 \\
\hline \multicolumn{3}{|l|}{ Evde yemek yerken sosyal mesafeyi koruma } \\
\hline Evet & 37 & 29,4 \\
\hline Hayır & 89 & 70,6 \\
\hline \multicolumn{3}{|l|}{ Kilo alımı } \\
\hline Evet & 86 & 68,3 \\
\hline Hayır & 40 & 31,7 \\
\hline Toplam & 126 & 100,0 \\
\hline
\end{tabular}

Covid-19 pandemisinde öğrencilerin ev temizliğinde sulandırılmış çamaşır suyu kullanımı; günlük sık kullanılan eşyaları, yüzeyleri, kapı kollarını çamaşır suyu ile temizleme; tuvalet, banyo gibi yerleri günlük temizleme; evi iki saatte bir havalandırma sıklığının $\operatorname{artt}_{\text {ğ }}$ saptand $1(\mathrm{p}<0,05)$.

Öğrencilerin bir metre sosyal mesafe koyma; hastalık bulgusu olsun/olmasın yüz maskesi takma; dişarıdayken gözlere, burnuna ve ağza dokunmama; tokalaşmama oranlarının pandemi öncesine göre arttığı saptand $1(\mathrm{p}<0,05)$.

Öğrencilerin Covid-19 pandemisinde dişarıdan gelindiğinde kıyafetlerini en az 60 derecede yıkama; eşya, poşet ve çantayı balkonda en az 3-4 saat bekletme; cep telefonunu alkol ve dezenfektanla temizleme, duş alma hijyen uygulama sıklığının arttığı bulundu $(\mathrm{p}<0,05)$.

Öğrencilerin kişisel hijyen uygulamalarından yemek sırasında mutfak eşyalarını (tabak, çatal, kaşık vb) paylaşmama; elleri sabun ve su ile en az 20 saniye yıkama; kontamine nesnelere dokunduğunda elleri yıkama, ellerin yıkanmadığı durumlarda bir kolonya veya dezenfektan solüsyon kullanma; havluyu tek kullanma uygulamaları pandemi öncesine oranla artt1ğ1 tespit edildi $(\mathrm{p}<0,05)$. Covid-19 pandemisi öncesi ve sonrasında öğrencilerin hijyen uygulamalarının dağılımı ve analizi Tablo IV'de verildi.

Tablo IV. Covid-19 Pandemisi Öncesi ve Sonrasında Öğrencilerin Hijyen Uygulamalarının Dağlimı

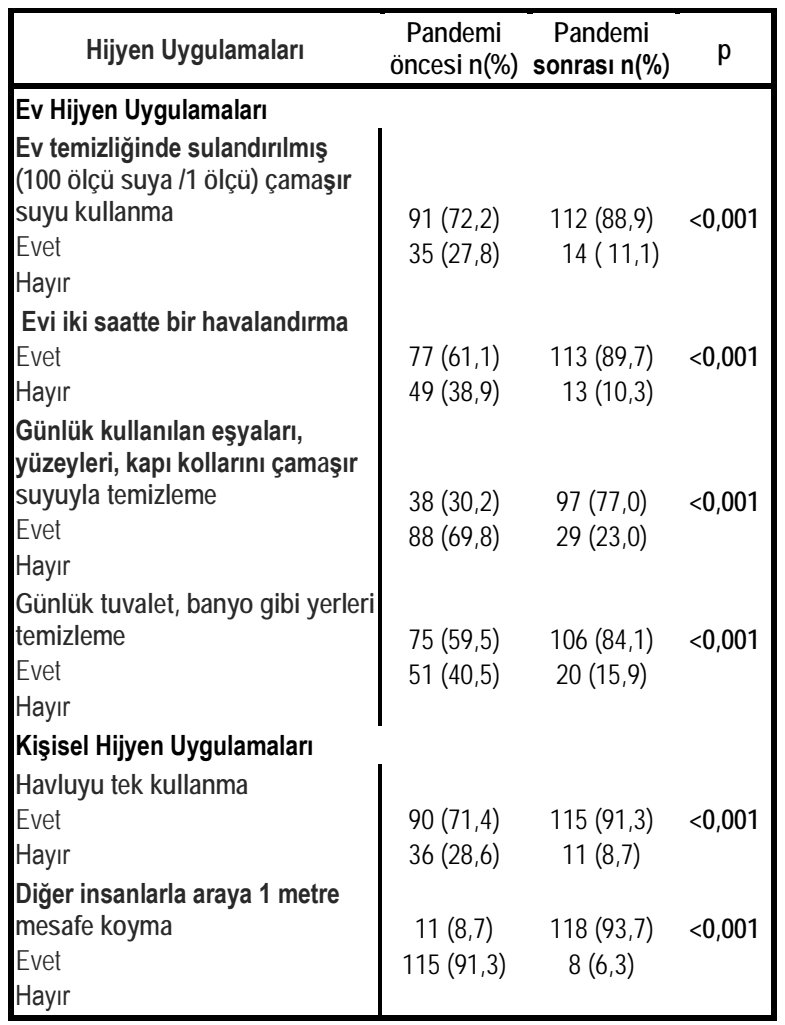


Tablo IV. (Devamı)

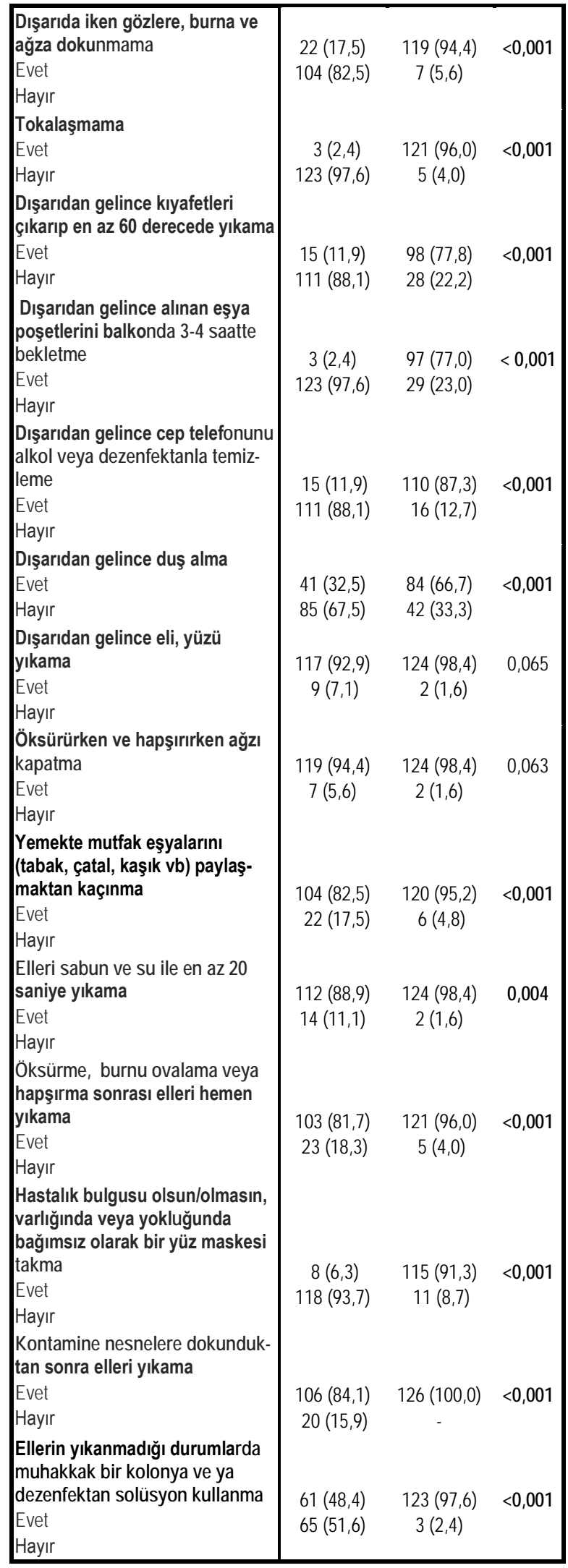

\section{Tartışma ve Sonuç}

Covid-19 pandemisinin hemşirelik öğrencilerinin beslenme ve hijyen alışkanlıklarına etkisini belirlemek için planland.

$\mathrm{Bu}$ çalışmada öğrencilerin yaş, cinsiyet gibi sosyodemografik özelliklerinin beslenme ve hijyen alışkanlıklarını etkilemediği saptandı. Yapılan bir çalışmada cinsiyet, yaş, eğitim ve mesleki geçmiş, hastalık öyküsü, Covid-19'a gösterilen ilgi, bilgi beslenmeyle ilgili gıda tutum ve uygulamalarını etkilediği saptanmıştır ${ }^{15}$. $\mathrm{Bu}$ çalıșmada öğrencilerin aynı yaș ve eğitim seviyesine sahip olmaları sonucu etkilemediği düşüncesindeyiz.

\section{Öğrencilerin Beslenme Allşkanlıkları:}

Viral enfeksiyonun etkisini sınırlamak halk sağlığını iyileştirmek için bağışıklık sistemini güçlendirici beslenme önerileri tavsiye edilmektedir ${ }^{16}$. Bu çalışmada öğrenciler Covid-19 sürecinde bağışıklıklarını güçlendirmek için günlük $\mathrm{C}$ vitamini, kurubaklagil, prebiyotik, probiyotik, zerdaçal, zencefil gibi baharat ve bitki tüketimini pandemi öncesine göre artırırken, asitli/gazlı içecek, abur cubur gibi sağlıksız besinleri azalttı. Bu çalışmaya benzer İtalya'da yapılan bir çalışmada Covid-19 esnasında katılımcıların ev yapı$\mathrm{m} 1$ tarifleri (tatl, pizza ve ekmek), tahıl, baklagilleri, beyaz et, taze balık ve sıcak içecekleri pandemi öncesine göre artırdığı; paketlenmiş hazır tatlı ve pişmiş ürünler ile alkol alımını azalttığı saptanmıştır. Çinli yetişkinlerin Covid-19 salgınıyla sebze, meyve ve su alımını artırarak, şekerli içecekleri ve atıştırmalıkları azaltarak diyet alışkanlıklarını değiştirdiği tespit edilmiştiir ${ }^{15}$. Karantina gibi zorunlu yaşam değişiklerine sebep olan bu olumsuz sürecin doğru beslenme alışkanlıkları kazanmada firsat olabileceği düşüncesindeyiz. Literatürde karantinanın getirdiği ekonomik sebepler, gıda depolanması nedeniyle paketlenmiş uzun raf ömrüne sahip işlenmiş besinlere tercih edileceği bildirilmektedir ${ }^{14}$.

Bu çalıșmada öğrencilerin karantina süresince evde daha çok yemek yaptığı, yemek yapmaya ayrılan zamanın ve çeşitin ve evde ekmek yapma oranının arttığı ve yarıdan fazlasının kilo aldığı bulundu. Bu çalışmaya benzer olarak İtalya'daki çalışmada karantina sürecinde katılımcıların yemek yapma isteğinin arttığı, yoğrularak yapılan ev yapımı tatlı, pizza, ekmek tercih ettiği, iştahlarının arttığı ve neredeyse yaklaşık yarısının kilo aldığı belirlenmiştir ${ }^{11}$. Karantinanın getirdiği zorunlu yaşam tarzı, sosyal izolasyonun getirdiği psikolojik etkiler, gıda depolama, obejenik ev ortamı, psikolojik yeme isteği, hareketsizlik kilo almaya neden olduğu düşünülmektedir. Bunu önleyebilmek için ekmek gibi unlu mamüller yerine taze sebze ve meyveler, ev içerisinde hareket, uyumadan önce yemek 
yememe gibi sağlıklı beslenme konusunda eğitim verilmesi önerilmektedir.

$\mathrm{Bu}$ çalışmada öğrenciler pandemi öncesinde alışveriş merkezlerini tercih ederken pandemi ile online alışverişe yöneldi. Sosyal izolasyon, karantina bireylerin tüm yaşam alanlarında etkili olduğu gibi alışveriş alışkanlıklarını da etkileyerek online hale dönüştürdüğ̈̈ görülmektedir.

\section{Öğrencilerin Hijyen Alışkanlıkları:}

Aş1lar ve hijyen önlemleri akut solunum yolu dahil olmak üzere enfeksiyonların yayılmasını ve etkisini sınırlamaya yardımcı olan önemli halk sağlığı önlemleridir ${ }^{16}$. Bu pandemide toplumsal bulaşmanın önüne geçebilmek bulaş riskini azaltabilmek için toplumun uyması gereken sorumlulukları bulunmaktadır. Bunlar elleri sık sık yıkamak, yıkamanın mümkün olmadığı yerlerde dezenfektan kullanmak, kontamine olmuş bir ortamdan sonra yüz ve ağızla temastan kaçınmak, sosyal mesafe, kalabalık ortamlardan kaçınma, maske kullanma, ev temizliğinde sodyum hipoklaritle seyreltilmiş içerikle temizleme, kontamine olmuş kıyafet, çarşafları $60-90^{\circ} \mathrm{C}$ derecede yıkama sayılabilirr ${ }^{8}$. Bu çalışmada öğrenciler ev hijyeni için pandemi öncesinde \% 72,2'si ev temizliğinde çamaşır suyu kullanırken pandemiyle bu oran \%88,92'a; \%61,1'i pandemi öncesinde evi iki saatte bir havalandırırken pandemiyle bu oran \%89,7’ye; \%59,5’i günlük tuvalet, banyo gibi yerleri temizlerken pandemiyle bu oran \%84,1; \%30,2'si günlük kullanılan eşyaları, kap1 kollarını çamaşır suyuyla temizlerken pandemiyle bu oran \%77'e çıktı. Japon halkının kişisel koruyucu önlemleri uygulama durumunu belirlemek amaciyla yapılan çalışmada rehberlerin standartlarında uygulayan \% 6,5' iken biraz esnek uygulayanlar \% 34,7'dir. El hijyenine \%83,8'ü esnek standartlar da uygularken rehberlerin istediği standartları ancak \%58,5'i uyguladığ 1 tespit edilmiştir. Esnek standartlarda el yıkama sayısı günlük ortalama $6 \mathrm{kez}$ bulunmuştur ${ }^{17}$. Bu çalışmada öğrencilerin kişisel hijyen uygulamalarından; havluyu tek kullanma pandemi öncesinde \%71,4 iken pandemi sonrasında $\% 91,3$; yemekte mutfak eşyalarını paylaşma pandemi öncesinde \%82,5 iken pandemi sonrasinda \%95,2; elleri sabun ve suyla en az 20 saniye y1kama pandemi öncesinde \% 88,9 iken pandemi sonrasında \%98,4; öksürme, burnu ovalama veya hapşırma sonrası elleri yıkama pandemi öncesinde \%81,7 iken pandemi sonrasında \%96; kontamine nesnelere dokunduktan sonra elleri yıkama pandemi öncesinde \%84,1 iken pandemi sonrasında \%100 bulundu. Kişisel hijyen uygulamalarının pandemi öncesinde yüksek olması hemşirelik eğitiminde önemli bir yere sahip hijyen uygulamalarını bilmelerinden kaynaklanmaktadır.

Bu çalışmada öğrencilerin kişisel hijyen uygulamalarından; sosyal mesafeye uyma pandemi öncesinde \%8,7 iken pandemi sonrasında \%93,7; dışarıdayken gözlere, burna, ağıza dokunma pandemi öncesinde $\% 17,5$ iken pandemi sonrasında \%94,4; tokalaşmama pandemi öncesinde \%2,4 iken pandemi sonrasında \%96; dışarıdan gelince eşya poşetlerini balkonda 3-4 saatte bekletme pandemi öncesinde \%2,4 iken pandemi sonrasında $\% 77$; dışarıdan gelindiğinde cep telefonunu alkol ve dezenfektanla temizleme pandemi öncesinde \%11,9 iken pandemi sonrasında \% 87,3; dışarıdan gelince duş alma pandemi öncesinde \%32,5 iken pandemi sonrasında \%66,7; hastalık bulgusu varlığında/yokluğunda yüz maskesi takma pandemis öncesinde \%6,3 iken pandemi sonrasında \%91,3; ellerin yıkanmadığı durumlarda kolonya ve dezenfektan kullanma pandemi öncesinde \%48,4 iken pandemi sonrasında \%97,6 olduğu belirlendi. Pandemi dönemine özgü olan uygulanan kişisel hijyen uygulamalarına çoğunun uyduğu gözükmektedir.

\section{Sinırlılıklar}

Araştırmanın sadece tek bir üniversite öğrencilerini kapsaması, literatürde Covid-19'un beslenme ve hijyen ile ilişkisi ile yapılmış araştırmanın azlığı.

\section{Sonuç}

Karantina gibi olumsuz görülen bir sürecin olumlu beslenme davranışı kazanmada etkili olduğu, diğer taraftan kilo artışına sebep olduğu bulundu. Eğitimlerle olumlu beslenme davranışı kazanma desteklenmeli, obezite gelişme riski açısından sağlıklı beslenme ve ev ortamında yapılabilecek fiziksel aktivite desteği konusunda bilinçlendirilme önerilmektedir.

Hemşirelik öğrencilerinin çoğunluğunun kişisel hijyen uygulamaları pandemi öncesinde de yüksek olduğu pandemiye özgü kişisel hijyen uygulamalarına yüksek oranda uyum sağlandığı tespit edildi. Toplumun sağl1ğına yön verecek hemşirelik öğrencilerinin kişisel hijyen uygulamalarını \%100 uygulamaları amaçlanarak girişimlerde bulunulması önerilmektedir.

\section{Etik Kurul Onay Bilgisi:}

Onaylayan Kurul: Bursa Uludağ Üniversitesi Sağlık Bilimleri Araştırma ve Yayın Etiği Kurulu.

Onay Tarihi: 01.07 .2020

Karar No: 2020-05/02

\section{Kaynaklar}

1. Bavel JJ Van, Baicker K, Boggio PS, et al. COVID-19 pandemic response. Nat Hum Behav. 2020;4(May).

2. Basch CH, Hillyer GC, Meleo-Erwin ZC, Jaime C, Mohlman J, Basch CE. Preventive Behaviors Conveyed on YouTube to Mitigate Transmission of COVID-19: Cross-Sectional Study. JMIR public Heal Surveill. 2020;6(2):e18807.

3. Nicola M, Alsafi Z, Sohrabi C, Kerwan A, Al-jabir A. Since January 2020 Elsevier has created a COVID-19 resource centre with free information in English and Mandarin on the novel coronavirus COVID- 19. The COVID-19 resource centre is 


\section{Covid-19 Pandemisinin Öğrencilere Etkisi}

hosted on Elsevier Connect, the company's public news and information . 2020;(January).

4. Demirbilek Y, Pehlivantürk G, Özgüler ZÖ, Alp Meşe E. COVID-19 outbreak control, example of ministry of health of Turkey. Turkish J Med Sci. 2020;50(SI-1):489-494.

5. Salzberger B, Buder F, Lampl B, Ehrenstein B, Hitzenbichler F, Hanses F. Epidemiologie von SARS-CoV-2-Infektion und COVID-19. Der Internist. 2020:1-5.

6. Dağcığlu B F, Keskin A. Covıd-19 Pandemisi Sürecinde Türkiye, Avrupa Ve Amerika Verilerinin Karşılaştırılması: Kesitsel Bir Çalışma Data Comparıson Of Turkey, Europe, And USA Durıng Covid-19 Process: A Cross-Sectıonal. 2020;2:360369.

7. Adhikari SP, Meng S, Wu Y, et al. Epidemiology, causes, clinical manifestation and diagnosis, prevention and control of coronavirus disease (COVID-19) during the early outbreak period : a scoping review. 2020:1-12.

8. Güner R, Hasanoğlu İ, Aktaș F. Covid-19: Prevention and control measures in community. Turkish J Med Sci. 2020;50(SI-1):571-577.

9. Darlenski R, Tsankov N. Since January 2020 Elsevier has created a COVID-19 resource centre with free information in English and Mandarin on the novel coronavirus COVIDresearch that is available on the COVID-19 resource centre including this COVID-19 pandemic and the skin: w. 2020;(January). 10.1016/j.clindermatol.2020.03.012.
10. Fong MW, Gao H, Wong JY, et al. Nonpharmaceutical Measures for Pandemic Influenza in Nonhealthcare Settings Social Distancing Measures. 2020;26(5).

11. Renzo D, Med JT, Renzo L Di, et al. Eating habits and lifestyle changes during COVID - 19 lockdown: an Italian survey. J Transl Med. 2020:1-15.

12. Aman F, Masood S. How Nutrition can help to fight against COVID-19 Pandemic. Pakistan Journal of Medical Sciences.2020;36:121-123.

13. Butler MJ, Barrientos RM. Brain, Behavior, and Immunity The impact of nutrition on COVID-19 susceptibility and long-term consequences. Brain Behav Immun. 2020;87(April):53-54.

14. Naja F, Hamadeh R. Nutrition amid the COVID-19 pandemic : a multi-level framework for action. Eur J Clin Nutr. 2020.

15. Luo J, Thomson CA, Hendryx M, et al. Accuracy of selfreported weight in the Women's Health Initiative. 2018;22(6):1019-1028.

16. Calder PC. Nutrition, immunity and COVID-19. 2020.

17. Machida M, Nakamura I, Saito R, Nakaya T. International Journal of Infectious Diseases Adoption of personal protective measures by ordinary citizens during the COVID-19 outbreak in Japan. Int J Infect Dis. 2020;94:139-144. 
